\title{
The Global Energy Transition and the Global South
}

\author{
Andreas Goldthau, Laima Eicke, and Silvia Weko
}

\section{Introduction}

The global energy transition, that is the full decarbonization of the world energy system until 2050, is attracting growing attention in global policy debates. While the geopolitics of the renewable transformation have attracted much recent attention (Goldthau 2017; IRENA 2019; O'Sullivan et al. 2017; Scholten 2018), the scholarly community has been surprisingly silent on what the low-carbon shift means for the Global South.

To be sure, there exists a host of writings on the development implications of renewables. A key theme here is improving energy access by decentralized electricity supply, notably in rural Africa or developing Asia (Alstone et al. 2015; Dagnachew et al. 2017). Other works center on the opportunity for developing countries to leapfrog centralized energy systems and instead make off-grid solutions the backbone of an economic development model (Kuzemko et al. 2016; Levin and Thomas 2016). Important reference points in this debate are the Sustainable Development Goals (SDGs), notably SDGs 3 (health and well-being) and 7 (centering on affordable and modern energy), which may be helped by a surge in renewable energy, prompting scholars to point to the co-benefits of the energy transition (Edenhofer et al. 2014; Helgenberger et al. 2017). Some works also zoom in on individual states (Baker et al. 2014; Power et al. 2016), highlighting the importance of the domestic political economy underpinning the energy transition.

That said, little scholarly attention is paid to the energy transition and the Global South beyond the fate of producer economies and the developmental state. Developing countries will be central, as $70 \%$ of the future energy demand is expected to come from non-OECD countries in 2040 (IEA 2018b), thanks to rapidly growing populations and economies. Among these, many developing countries in sub-Saharan

\footnotetext{
A. Goldthau $(\varangle) \cdot$ L. Eicke $\cdot$ S. Weko

IASS, Potsdam, Germany

e-mail: Andreas.Goldthau@iass-potsdam.de 
Africa, South East Asia or Latin America are confronted with the imperative to foster economic development but at the same time lack the domestic capacity to ensure this is done in a sustainable way. China, India, and Brazil, by contrast, have large enough markets to make up for some of the potential risks for companies to do business there, and have proven capable of 'catching up' in many areas, including the (low carbon) energy domain. ${ }^{1}$ The focus of the present analysis therefore is on the 'nonBRICS Global South', that is on developing countries other than the large emerging economies.

This chapter seeks to fill an apparent scholarly gap and offer a 'Global South perspective' by shedding light on the specific circumstances pertaining to countries of the Global South. More to the point, it argues that countries in the Global South may face a specific set of challenges in their efforts to embrace a low-carbon future (Sect. 2). Empirically, the chapter zooms into the trias of technology, finance, and trade, and suggests that there exist structural barriers and uncertainties that require the attention of scholars and policymakers (Sect. 3). Theoretically, it offers three different conceptual lenses on the low-carbon transition and the Global South, drawing on realist International Political Economy (IPE), critical IPE, and dependency theory (Sect. 4). A final section concludes.

\section{A Global South Perspective on the Energy Transition}

\subsection{Innovation, Investment, and Low-Carbon Modes of Production}

Judging by their cost curves, renewable technologies have entered the stage of market maturity. The unit costs of solar PV fell by around $90 \%$ over the past decade (IRENA 2019), and similar dynamics have unfolded in onshore wind turbines. This is largely a function of scale effects and a surge in global investment in renewable energy capacity. Low-carbon technologies are now cost-effective sources of power and have in many regions resumed a top place in power investment (IEA 2019).

That said, there exist significant differences in the distribution of global capital allocation (see Fig. 1). Northern America, Europe, and China are the top destinations of global investment in renewable energy. Within the developing world, the bulk of investment essentially goes to three countries: China, India, and Brazil. Other developing countries received a mere $12 \%$ of the total investment volumes of USD 280 billion in 2017 (UNEP/BNEF 2018). It is likely that this trend will continue, as the underlying investment decisions reflect public policies favoring renewables and a strong market pull stemming from sizeable economies. This lopsided investment pattern in renewables is in line with energy investment more generally. As the IEA

\footnotetext{
${ }^{1}$ This is evidenced by investment flows, among other (Murphy et al. 2015). Especially China should not be considered as a developing country due to its unique set of circumstances (Watson and Byrne 2012).
} 


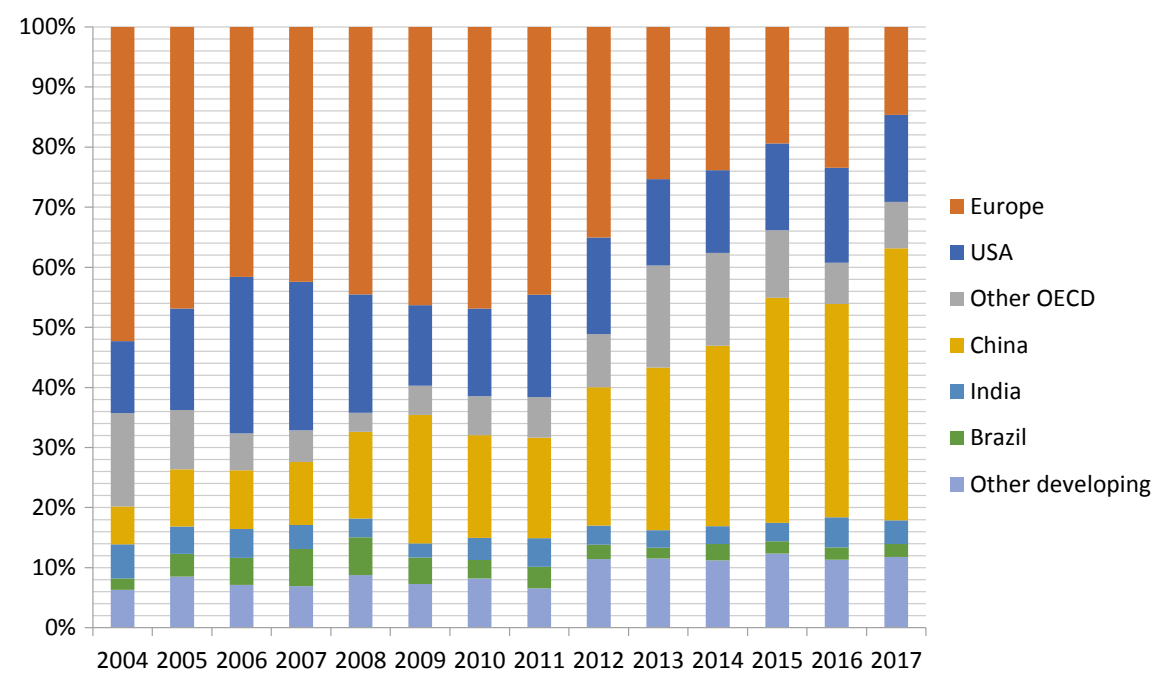

Fig. 1 Geographical distribution of investment in renewable energy. Source (UNEP/BNEF 2018)

estimates, middle-to low-income countries accounted for some $14 \%$ of overall investment in 2017 , but represent $41 \%$ of the world's population. By contrast, high-income countries, representing less than $15 \%$ of the population, received more than $40 \%$ of investment volumes (IEA 2019).

To be sure, from a climate policy perspective it is highly desirable that investment in low-carbon energy sources is geared toward large (emerging) markets, as these will generate the bulk of GHG emissions increases in the near future. Yet, with a view to the SDGs, it is detrimental if (private) capital shies away from low-income economies, as it means perpetuating the energy access problem. Moreover, it is typically less developed countries (LDC) economies where most of the economic growth potential lies, given their generally young population (Gribble and Bremner 2012). Ensuring sustainable development in low-income countries would therefore require sufficient investment in low-carbon energy sources, setting them on a climatefriendly growth path. In fact, finance needs in mitigation technologies are found highest among developing nations (Tempest and Lazarus 2014).

A second challenge pertains to the fact that low-carbon technology remains concentrated in terms of ownership. Judging by the number of patents in the low-carbon technology domain, technology leadership essentially lies in the OECD world and China. Only few developing economies joined this rather exclusive club, and if at all, then only on a very selective basis. Brazil and Mexico, for instance, have become players in the field of biofuels, whereas Russia managed to catch up in the wind sector (IRENA 2019). The upshot is, however, that low-carbon technology innovation happens in the North, not the South.

In this context, observers have repeatedly pointed to the health sector for it exhibits structural similarities (Abbott 2009; Chon et al. 2018). Notably, intellectual property 
rights (IPRs) for drugs tend to be concentrated in OECD nations. IPRs are governed by stringent regimes protecting the right of the innovator to recoup significant upfront costs. In the health sector, fierce debates emerged around developing countries' access to essential medicines, and the question which good is more valuable: the private good of an IPR, or the public good of a population's health and wellbeing. Such arguments have been made also in the context of the UNFCCC, where representatives of the developing world raised the issue of IPRs as a potential impediment to their sustainable development and successful energy transition (Ockwell et al. 2010; Zhou 2019).

While it remains contested whether the pharma and the low-carbon tech sectors indeed are comparable, the more fundamental point here is a 'technology gap' (Castellacci 2011) facing many countries in the Global South, a cause of persisting underdevelopment and indeed poverty (Fofack 2008). Observers have therefore made the argument that efforts to foster access to low-carbon technologies are likely to generate a 'development dividend' in LDCs (Forsyth 2007). Note that this is about more than simply ensuring climate-friendly energy supply and energy access. It is about facilitating a low-carbon mode of production for any good or service a given country feeds into global value and supply chains. The rationale here is as simple as it is straightforward: as climate policies progress and become a determinant also in global trade, a low-carbon footprint ensures a country's products stay competitive in the global market. Short of access to low-carbon technologies, developing nations may therefore face the risk of being cut out of global trade relations through such mechanisms as carbon border adjustment, which has been lauded by economists (Akerlof et al. 2019) and planned at the EU level (Horn and Sapir 2019).

In this context, and as discussed in further detail below, countries rich in fossil fuels are believed to face a specific challenge. Predominantly found in the Global South, producer economies are typically locked in a resource-dependent economic model. Many qualify as rentier states and are trapped in a 'resource curse' that makes the extractive sector their dominant industry (Auty 1993; Ross 2012; Schwarz 2008). As research has shown, there exists great potential for solar and wind farming in the Gulf, Northern Africa or the Gulf of Guinea (IRENA 2018; Kruyt et al. 2009), world regions that at present are home to prime fossil fuel exporters. The low-carbon energy transition therefore presents these countries with the opportunity to embrace a new economic model based on industrial diversification. Yet leaving aside questions of political will (many resource-rich countries have shied away from diversifying their economies in the past), administrative capacity and technical expertise, it has been suggested that it will be hard for such states to leave the carbon-intensive development pathway that characterizes their socioeconomic system (Friedrichs and Inderwildi 2013). In other words, the development challenge goes beyond ensuring access to pertinent low-carbon technology and embedding them in national systems of value creation. It is about replacing a path-dependent, fossil-based rentier state with a fundamentally different, low carbon-based economic model. 


\subsection{The Limits of Adopting a 'Global South' Perspective}

That said, there are clear limitations to what a 'Global South' lens can do for analyzing the global energy transition. It can only point out global trends and risks, and will not be able to account for the differences between Global South countries, which are clearly a heterogeneous group. Their differences in market size and investment risks, for instance, will mean that least developed nations clearly face more extensive risks and challenges than other developing countries, both in the realm of investment (Newell and Bulkeley 2017) and tech transfer (Ockwell and Byrne 2016). The degree to which Global South countries protect intellectual property rights may also impact their respective energy transitions, although this is a contested point and not one that can be addressed in detail here (see for example Abdel-Latif 2014; Ockwell et al. 2010; Pirrong 2014; Raiser and Bruhn 2017). Neither can a 'Global South perspective' address the national-level dynamics, which also shape energy transitions. Some challenges for developing countries in the energy transition are specific to their national political economies, such as governance and capacities (Jordana et al. 2006) and the interests of incumbent players (Baker et al. 2014).

\section{Three Challenges for Countries in the Global South}

Clean tech, finance, and trade are key elements for a successful transition to a lowcarbon future. This section discusses these three elements with a view to identifying challenges and barriers for the case of the Global South.

\subsection{Technology and Value Chains}

A first challenge comes with the way value is captured in the global value chain (GVC) for low-carbon technology. Renewable energy magnifies the importance of technology for value creation due to the zero marginal cost problem: the resource such as the sun and wind is free, whereas the technology that converts energy and moves it to consumers earns money (see for example Overland 2019). Technology is made up of both hardware (equipment) and software, knowing to use and reproduce or improve upon hardware (Ockwell et al. 2010). Such technology is one of the most valuable parts of the value chain, which is a series of steps for a product or service to move from its conception to end use (Gereffi et al. 2005). In general, product development and design are more valuable than other activities such as resource extraction (Gereffi and Lee 2012). As global innovations systems scholars have elaborated, clean tech valuation differs between industries according to their standardization vs. customization, which is not static (Binz and Truffer 2017). Nevertheless, the value chains for low-carbon energy technologies may be categorized as producer-driven, 
which are 'capital, technology, or skill-intensive industries' with the potential for large, vertically integrated firms to control the production system (Gereffi 2014).

The value chains for low-carbon energy tech are quickly globalizing. Where solar PV was previously produced by vertically integrated firms within a country or region, its "production is now governed by multiple value chains made up of vertically specialized, and some integrated, firms, spanning across multiple countries" (Meckling and Hughes 2017: 227). This increased geographical scope presents the opportunity for technology diffusion and transfer, ${ }^{2}$ which Bell (1990) conceptualizes as taking place in three flows: (A) the flow of capital goods and services; (B) skills and knowhow to use and maintain technologies; and (C) skills and knowledge necessary to create technical change. While the first two flows may result in the diffusion of low-carbon energy technologies and green growth, only the third stream enables innovation. The prerequisite for this to take place is 'absorptive capacity' which involves high levels of human capital and is especially important for complex technologies (Bell's more recent work also focuses on low-carbon tech in particular, see Bell 2012).

However, not all countries will be able to benefit from globalizing value chains, and the Global South in particular risks being shut out. Many developing countries remain excluded from international technology flows (Glachant and Dechezleprêtre 2016). This is because international private developers see politically unstable countries as too risky of an investment; and in very poor countries or regions there is no market case for private industry to participate (Kirchherr and Urban 2018). The possibility for countries to escape infrastructural and technological carbon lock-in depends on the costs of moving away from high-carbon systems and options for alternatives (Seto et al. 2016). Therefore, in those countries which are currently not attractive for clean tech investments and do not participate in low-carbon tech value chains, existing technologies and infrastructure will resist changes. Some mechanisms exist to transfer low-carbon technology when private firms will not invest, led by international institutions (Abdel-Latif 2014; Ockwell and Byrne 2016; Rimmer 2019) and public-private partnerships (Chon et al. 2018). The extent to which such mechanisms succeed in transferring technology is unclear, but developing countries excluding the big three have remined below their potential (Edenhofer et al. 2014). This suggests that the carbon lock-in risk remains.

Countries which are attractive for investors in installing or producing low-carbon energy technologies may become a part of the global energy value chain and achieve co-benefits like better environmental quality and more jobs. However, in clean energy industries which are research- and technology-intensive, the most lucrative part of the value chain is tech development, which is centered in the US, EU, China, and Japan (Curran 2015; Nahm 2017). Most Global South countries lack the absorptive capacity to innovate on transferred hardware and therefore 'upgrade' within the value chain if they do not also receive 'software'. A key exception to this is China: its high

\footnotetext{
${ }^{2}$ We use the IPCC 2000 definition of technology transfer: "a broad set of processes covering the flows of know-how, experience and equipment for mitigating and adapting to climate change amongst different stakeholders" (Metz et al. 2000: 3), which is a commonly used definition.
} 
local innovative capacity, combined with industrial policies such as local content requirements, helped its firms capture value and upgrade in the clean energy value chain (Gosens and Lu 2013; Schmitz and Lema 2015; Zhang and Gallagher 2016). Yet such industrial policies may not succeed in countries with small markets, poor regulatory design and coherence, or low industry/innovation potential, and has only seen moderate success even in large markets such as India (Johnson 2016). Whether or not the Chinese experience can be recreated in other Global South countries with the help of tech transfer initiatives remains unclear. Preliminary research on lowcarbon tech transfer initiatives suggests that initiatives mainly focus on transferring hardware rather than software, which will help clean technology diffuse, but not encourage indigenous innovation capacities or widespread entry into value chains (see Fig. 2).

If Global South countries do not build up indigenous capacities, they may become dependent on the Global North for low-carbon technologies, which comes with two potential risks: increased trade litigation and political tensions, and monopolies. Work by Lewis (2014) has shown that substantial trade imbalances between renewable energy technology manufacturers and users resulted in increased international trade litigation and escalating trade tensions. While Lewis' work focuses on actors in the EU, the US, and China, this pattern may be exacerbated if Global South countries become technology users without upgrading within GVCs. North-South tensions may also be exacerbated in the international political arena, as a lack of access to low-carbon tech has already been a stumbling block for UN climate negotiations (Abdel-Latif 2014). Currently, many nationally determined contributions (NDCs) are conditional on climate finance and the transfer of low-carbon tech to meet their goals, and calls for low-carbon tech transfer have included discussions of compulsory

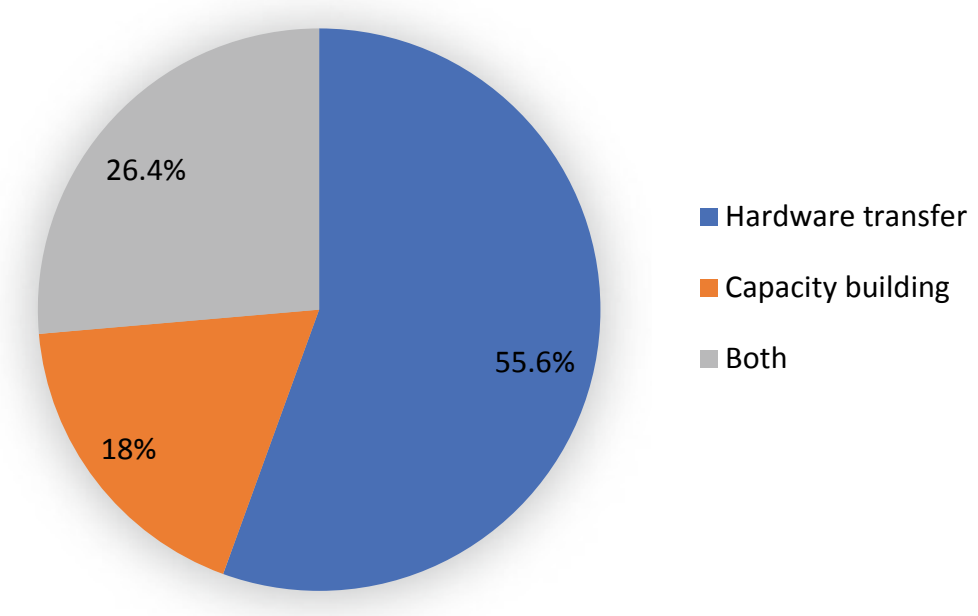

Fig. 2 Focus of global tech transfer initiatives. Source Own data 
licensing which have been strictly opposed by the EU and the US (Pueyo et al. 2012). In addition, because low-carbon tech value chains are producer-driven, large, vertically integrated firms have the potential to monopolize production. Already authors have argued that the current system uses IPRs to prevent market entry and follow-on innovation (Baker et al. 2017; Raiser et al. 2017). Monopolies allow technology producers to distort markets, and this dynamic may be worsened if the Global South is increasingly dependent on low-carbon tech from a few powerful actors, rather than having developed indigenous technologies. This risk may be more pronounced for some technologies such as wind power, while solar PV may be less likely to develop captive value chain governance (Binz and Truffer 2017).

\subsection{Financial Risk and Path Dependency}

A second challenge pertaining to the global energy transition and the Global South are financial transition risks facing particularly resource-rich countries. Today, many developing countries of the Global South find themselves at the crossroads between trying to leapfrog carbon-intensive industrial production, and replicating the carbon lock-in that characterizes the developed countries' rise to industrial powerhouses. As many countries only start shaping their future national energy systems, today's decisions matter: the infrastructure built now will be determining these countries' energy mix for decades to come (Seto et al. 2016). Yet, carbon lock-in is not only contingent on domestic factors, but also external actors. A case in point is Chinese overseas investments in fossil fuels, which amounted to USD 128bn in comparison to only USD 32bn in renewables between 2000 and 2018 (Gallagher et al. 2018; Wright 2018). Such investments create path-dependent positive returns in fossil infrastructure which has the potential to delay the adoption of low-carbon technologies and the deployment of renewables despite their economic viability for decades (Unruh 2000; Unruh and Carrillo-Hermosilla 2006). This may seriously impede low-carbon future development pathways of the recipient countries of such investments. Leaving such a lock-in is possible, but comes with high transaction costs as it requires changing long-established infrastructure, rules, and (economic and political) institutions (Seto et al. 2016).

This point extends to another aspect, which is the significant exposure of carbon locked-in countries to several elements of financial risk. One such risk which has been widely discussed is that of stranded assets. In essence, the challenge here consists in the looming devaluation of fossil fuel assets held on public and private balance sheets. As the 2015 Paris Agreement to limit global warming to well below $2{ }^{\circ} \mathrm{C}$ implies two-thirds of known fossil fuel reserves need to remain unexploited (IEA 2018b), much of the oil, gas, or coal currently held in the books will not be monetized. The question therefore is not whether, but when these assets will be devalued and become 'stranded'. Estimates go up to \$100 trillion losses in fossil fuel assets' value until 2050 (CitiGPS 2015). Modeling suggests that the resulting global 'carbon bubble' could lead to losses comparable to the 2008 financial crisis (Mercure et al. 2018). As 
the IEA estimates, oil and gas producer states bear the risk of some USD 7 trillion losses in income in a Paris scenario: Nigeria risks a decrease of about 500 billion in income, Saudi Arabia could lose almost USD 2 trillion and the United Arab Emirates faces the risk of some USD 900 billion in foregone revenue (IEA 2018a).

A related question pertains to the distribution of such financial risks: that is, who will be hit first and with which impacts. It has been argued that in the OECD, fossil fuels are mainly held and exploited by publicly traded companies, which typically have lower reserve-to-production ratios and more flexible business models as compared to their state-owned peers (NOCs) elsewhere. Moreover, the majority of crude and gas reserves are in state hands. This implies a higher degree of vulnerability and indeed risk for countries of the Global South and their NOCs (Krane 2017). Investment in fossil fuel based energy infrastructure in the face of rising energy demand in many developing countries further enhances this risk (Seto et al. 2016).

Short of decisive transition management, some countries might come under twin pressure: they may lose resource rents whose redistribution ensures social stability, but in some cases also domestic support for autocratic rule; at the same time, they may face deteriorating terms of trade as their exports might decrease in relation to imports and hence mounting pressure on their currencies. At worst, the financial risk of stranded assets may become a political risk of 'stranded nations' (Manley et al. 2017 ) with possible implications for the stability of the international system. The global energy transition therefore flips the logic of 'resource curse' (Karl 1997) on its head: it no longer is the abundance of economic rents, but rather them withering away faster than countries can adapt that creates problems for resource-rich states. Still, the implications might look similar to the ones observed today, especially poor economic performance (Sachs and Warner 1995), undemocratic tendencies (Ross 2001), and possibly even civil wars (Collier and Hoeffler 2004) (Fig. 3).

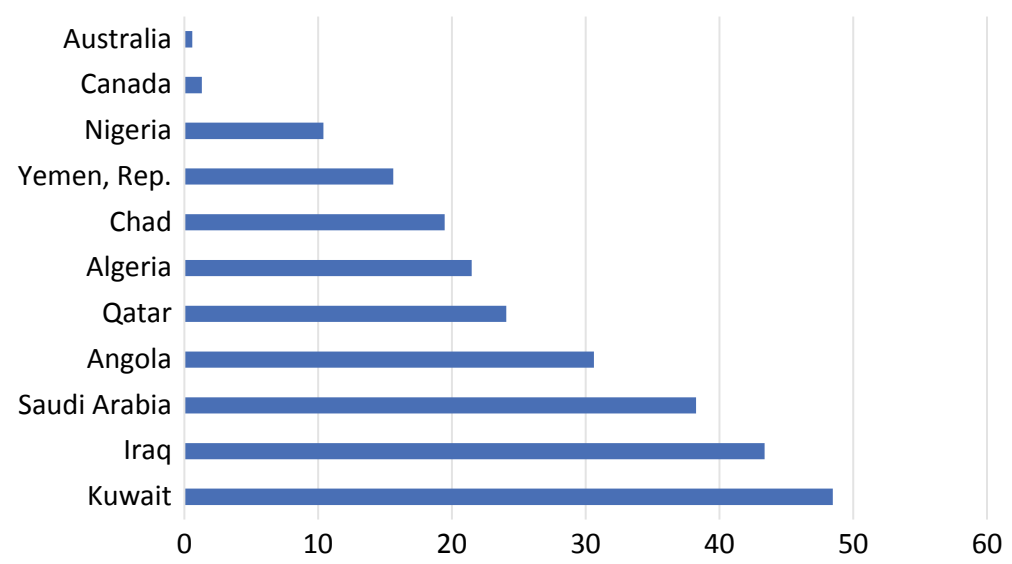

Fig. 3 Oil rents as percentage of GDP, average 2007-2017. Source World Bank, World Bank Open Data (https://data.worldbank.org/indicator/NY.GDP.PETR.RT.ZS), selected countries 


\subsection{Trade}

Finally, the global energy transition is susceptible to challenging incumbent global trade patterns in energy and electricity. A key question here is whether global trade in energy will increase or decrease. Underpinning this question is the fact that the global energy transition in principle enables every country to produce renewable energy, yet at different efficiency and cost levels. One scenario therefore suggests countries will become more self-sufficient and global energy trade will falter (Scholten 2018b). This could give importing states the upper hand in trade and also reduce pressure on trade routes of fossil fuels such as the Strait of Hormuz, which have repeatedly been the site of conflict. A contrasting view holds that trade volumes in energy will stay the same or even increase (Schmidt et al. 2019). Technology innovation in renewable fuels and Power-to-X are seen as increasingly enabling global trade in renewable energy. Different production conditions, but also different acceptance levels create price differences among countries, driving international trade. Some fossil fuel infrastructure such as gas pipelines might see second use cases in, e.g., hydrogen trade. This could reduce the risk of stranded investment and therefore also hedge the possible financial losses of decarbonization (Schmidt et al. 2019). Depending on which scenario will unfold, it will impact on the relations between today's energy net-importing countries, transit countries, and net exporting countries. Countries of the Global South will face the challenge to reposition themselves in this new, emerging energy trade order.

What is more, the global energy transition is likely to particularly impact regional integration dynamics in electricity trade. Regional electricity trade is expected to increase as part of the energy transition, as money can be made from cross-border balancing of fluctuations in renewables supply (Bahar and Sauvage 2013; Criekemans 2018: 46). This results in more interconnected cross-border electricity grids. Observers suggested that this gives an edge to countries dominating and owning regional grids, the most efficient producers and balancing states. The control over regional grid infrastructures such as power lines, storage, or software will become vital for national security and for projecting influence and power (Criekemans 2018: 47). Some have also suggested that regional integration might happen around powers centers in such networked grids (Goldthau et al. 2019). For instance, China heavily invests in the strategic build-up of grid infrastructure as part of its great Belt and Road Initiative. The Desertec project, planned to connect Europe to large North African solar plants, has failed so far, by contrast. As existing evidence from the EU and other world regions suggests, political stability, and mutual trust are, in addition to administrative capacity, crucial preconditions for effective governance structures of cross-border spanning grids-a challenging task for some countries and regions of the Global South.

A last element and indeed significant uncertainty lies in carbon-related trade measures. In a recent elite study we conducted among international energy experts and energy investors, $87 \%$ confirmed that the global energy transition will raise the importance of carbon content in products. Asked for the key driving forces behind 


\section{A strong push for decarbonisation will mainly be driven by..}

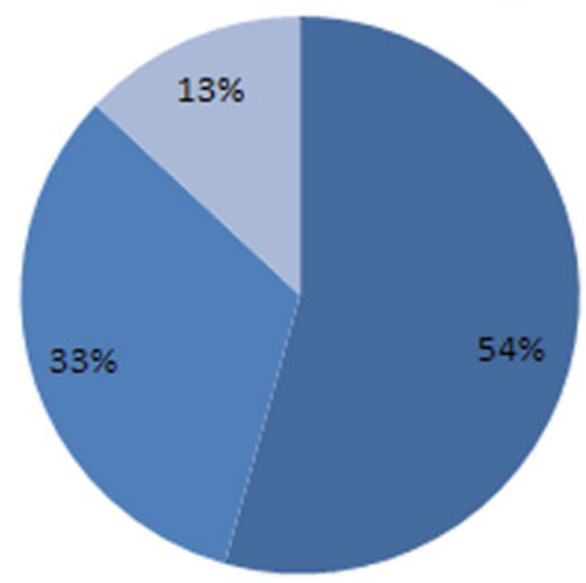

big economic blocs (e.g. EU) that will aggrevate access for carbon-intensive products

n consumers who will prefer low carbon products

global companies which will source from other countries instead

Fig. 4 Elite perceptions on drivers of decarbonization. Source Own data

this, $54 \%$ trade regulations by big economic blocs as much more important drivers than consumer preferences (33\%) or companies (13\%) (Fig. 4).

In fact, recent discussions in the EU have started to use trade regimes as a potentially powerful instrument to foster a global energy transition. A case in point are carbon border adjustments, which put a levy on carbon-intensive imports (Mehling et al. 2019). Such measures could level the playing field for domestic and foreign producers against the backdrop of more progressive climate policies in the EU, help to export the EU's decarbonization agenda, and strengthen the internationalization of own efficiency standards (Keohane et al. 2015). This discussion ties into a broader agenda of climate clubs, as championed by Nobel prize-winning William Nordhaus. Economic modeling and theory suggests that such a climate club, by effectuating small trade penalties on non-participants, is able to foster a large, stable coalition with high effects on carbon reductions (Nordhaus 2015). Once introduced, carbon border adjustments or even a coalition of climate clubs could have strong implications for trade relations with countries of the Global South, as not only direct trading partner countries but also large companies would most likely establish carbon content and efficiency requirements along their production cycle (see also Vandenbergh 2007). This goes back to the point made above, to the effect that a successful domestic energy transition would become prerequisite of a country's participation in global value and supply chains. 


\section{Three Conceptual Lenses on the Emerging Geopolitics of the Energy Transition}

A 'Global South perspective' on the global energy transition needs to go beyond merely describing the possible structural barriers pertaining to technology, finance, and trade. So how can we make sense of the three core aspects outlined above in more conceptual terms? We use three different conceptual lenses to interpret current dynamics pertaining to the low-carbon transition and the Global South, drawing on realist IPE, critical IPE, and dependency theory. Each of these reflects a specific strand in current policy debates on the global energy transition, and offers a distinct take on the technology, finance, and trade in that context.

\subsection{Realist IPE}

The first lens broadly trades under the rubric of realist IPE. Essentially relying on a state-centered perspective on International Political Economy (Gilpin 1987), realist IPE firmly links economics and high politics by positing that state interests are central to the shape and function of international economic relations. States strive for economic security, a goal which is considered equal to military security. In its nationalist reincarnation, realist IPE views economics as a source of power and supremacy, giving rise to a mercantilist approach in global political economy (Hamilton 1791; List 1841). An important aspect here is the balance of trade, which economic nationalists tend to view as an indicator of a country's relative strength or weakness vis-a-vis competitors on the international stage. Because state interests and economics are linked, the latter can become a function of the former, or vice versa, thus giving rise to the patterns of 'trade following the flag' or 'the flag following trade' (Baru 2012).

In the context of the global energy transition and the Global South, the important point here is that technology, trade or finance are considered a means to an end, rather than sectors of their own. More to the point, from a realist IPE point of view, low-carbon solutions cannot be assumed to globally diffuse thanks to free market forces, sufficient demand pull, and falling unit costs. Rather, they may be available depending on whether it is in the strategic interest of the very states these technologies originate from, and also of the organized incumbents in the recipient countries. Given their status as tech laggards, countries in the Global South may therefore risk becoming politically dependent on the goodwill of the major green technology patent leaders - China, the US, the EU, Japan, or Korea. Likewise, trade as such cannot be considered to happen on a global-level playing field. Instead, the flows of goods and services may be a function of strategic trade policies, facilitated by preferential regimes or prevented by select tariff or non-tariff barriers. Similar assumptions can be made regarding financial flows, whose allocation may be informed by states' desire to maintain a surplus in their current account balance, rather than a deficit, thus perpetuating the lopsided global distribution of RES investment (see Fig. 1). 
In short, such as lens suggests that all three aspects may become subject to 'an economics agenda for neo-realists' (Moran 1993).

From a realist IPE lens, the export of low-carbon products (like solar PVs) and services may help improving the trade balance and the current account. In turn, this means that keeping control over the technological know-how is imperative to ensure this effect to happen. As Meckling and Hughes (2017) have shown, for instance, states may take action to ensure certain parts of the renewable value chain remain on their territory. Or take renewable fuel trade, which may pick up thanks to advances in technology (Schmidt et al. 2019): from an economic nationalist perspective, it in principle does not make much difference whether it is fossil or green molecules that are imported, as both deteriorate the trade balance. It is therefore not inconceivable that states will try and curb imports of renewable fuels, not for reasons related to climate skepticism but because it is not considered in the national interest. This will result in global markets developing at a much smaller scale than technological advances would suggest or allow.

Moreover, as realist IPE comes with a mercantilist edge, there is no such thing as open and free trade. Energy technology transfer may be subject to strategic trade policies rather than business opportunity, and may even fall prey to geopolitical scheming (see also Goldthau et al. 2019). As the trend toward a retreat of the liberal order that started to unfold in the twenty-first century weakens multilateral frameworks such as the global trade regime, this may further exacerbate growing economic nationalism, also in the energy domain. For the Global South, this essentially implies that the Global South may fail to adequately profit from advances in low-carbon technology and be excluded from participating in renewable value chains.

\subsection{Critical IPE}

A second lens offered here is critical IPE, which promises insights into interactions between the state, markets, and society, zooming in on the underlying power structures. An obvious starting point here is Karl Polanyi (1957), whose term of a 'Great Transformation' has gained renewed attention in the context of the postfossil economy (Fraser 2017; WBGU 2011). At the most fundamental level, the deep decarbonization implied by the Paris Agreement will arguably indeed bring about profound change. The global energy transition is therefore likely to reshape not only interstate relations or international trade along the lines discussed above, but equally so the socioeconomic structure. And yet, there has been surprisingly little analysis of the energy transition from a critical international political economy perspective until now (see Newell 2019 for an exception).

To be sure, Polanyi's work centered on the rise of market capitalism in nineteenthcentury Great Britain. But some of the core concepts may offer useful starting points for the dynamics underpinning the global energy transition. His analysis of the rise of the market society, for instance, reminds us of the risk of 'disembedding' economic activity from the broader society, and of allowing this activity to develop its own 
distinctive laws. While the global energy transition arguably is about more than mere economic activity, elements of it clearly resonate with Polanyi's critique of subordinating nature and society to separate systemic logics. This extends to the notion of a 'double movement' between the competing dynamics of the expansion of market forces and societal protection. This concept could be put to work for analyzing dilemmas of the global energy transition: on the one hand, there exists the market-based globalization, creating social, and environmental externalities such as climate change. On the other hand, we witness the societal measures for protection, such as climate change mitigation and adaptation policies. Sometimes these policies aimed at ensuring human security and the habitat might in turn themselves foster the expansion of market dynamics, e.g., through the creation of carbon markets or REDD+ certificates, which in turn are mainly produced in countries of the Global South.

A rich tradition in Polyanian-inspired IR theory (see Dale 2016) may, further, inspire thinking about the implications for the international relations-or even the geopolitics - of the unfolding global energy transition. Critical development studies in particular offer important ways to conceptualize the 'marginalized others' (Inayatullah and Blaney 2016) in this context, that is countries of the Global South that may remain outside of what may emerge the dominant paradigm of a new 'climate capitalism' (Newell and Paterson 2010).

Antonio Gramsci's theory on hegemony (2011) may be another promising approach. A key focus of Gramsci's work rests on the historical-materialist factors underpinning large-scale transformations. In contrast to realist IPE, which by and large views states as black boxes, it is the intra-state power dynamics between contrasting forces that are central to the analysis, making the state a function of social relations. The supremacy of a ruling group is understood as hegemony, which is characterized by a mixture of coercion and consent, requiring the formation of selective compromises between rulers and ruled (Gramsci 2011). From a Gramscian lens, the global energy transition and the emerging climate capitalism may be well viewed as entailing an element of cultural (and indeed discursive) hegemony. Not only is it the Global North that arguably set the global policy agenda pertaining to the energy transition. It also defines the approach for addressing the climate challenge, which remains compatible with the incumbent capitalist paradigm. Such a perspective could also add to our understanding of the contemporary contestations surrounding the deep shifts facing the society's very material basis that is the energy system. Especially Gramsci's conceptualization of the state and its internal dynamics can guide analyses of the state's role as a transition manager in this process (Newell 2019).

A Gramscian approach may also add value to analyzing global dynamics. For instance, questions of access to technology and international finance may translate into vulnerabilities for countries in the Global South and therefore become subject to additional contestation. As Newell (2019) argues, the jury is out whether new actor constellations arising in a renewable energy world will lean towards 'trasformismo', referring to co-optation into a dominant coalition, in which potentially conflicting 
ideas become assimilated and incorporated (Cox 2016) rather than a great transformation of deep structural change in Polanyi's sense. It is also not inconceivable that it will give rise to a new counter-hegemony of emancipatory movements, rebelling against the globally unjust distribution of benefits, risks, and losses within the globalized production system of a global energy transition. Emerging debates around the imperative of a 'just transition' accounting for developing countries, marginalized groups, and economically vulnerable communities mirror this normative dimension underpinning the low-carbon shift.

\subsection{Dependency Theory}

A final lens on energy transitions and the Global South is dependency theory, which posits that a country's economic development potential is determined by its relative position within the economic structure of a world system. A key analytical category is the distinction between core and periphery within this system. Dependency theorists posit that given their peripheral status, some countries of the Global South may be structurally unable to catch up in terms of technological development. Whereas some transfer of technology occurs on the back of the influx of foreign capital, innovation processes remains concentrated in the center (Vernengo 2016). In the context of the global energy transition, the concentration of renewable technology patents can be seen as indicative for the perpetuation of the established OECD 'core' in the global economic system, complemented by the emergence of a select number of new core countries, notably China. ${ }^{3}$ The mere deployment of solar panels across the world does not do break the principle logic of replicating dependency relations of old.

This point extends to trade. Dependency theory would suggest that the core exports mainly advanced products, whereas the periphery delivers raw products and natural resources in return. In the energy sector, many countries in Africa and Latin America have indeed long served as exporters of oil, gas, or other resources, and may in part also resume that position when it comes to rare earth materials that are considered crucial for renewable energy technologies and electric vehicles. The OECD and China, in turn, are set to dominate the export of renewable technologies as well as related products and services, thanks to their role as innovation leaders. The underlying pattern here reflects some of the theory's structural assumptions on the typical international division of labor between center and periphery countries, perpetuating dependency relations. Importantly, resource exports are generally subject to higher price volatility than manufactured goods (Becker 2008), as illustrated by the notorious oil price fluctuations. The Prebisch-Singer effect also suggests that the terms of trade tend to deteriorate for primary commodity exporters, as the relative demand

\footnotetext{
${ }^{3}$ In terms of technological development, lessons may be drawn from the recent Chinese experience. China heavily relied on state support and steering coupled with domestic content requirement for foreign investment, thus ensuring technology transfer. What in the 1960s would have qualified as state-assisted import substitution industrialization (ISI) has proven a model for the 21 st century and gave rise to technology leadership in one of the most important sectors going forward.
} 
for resources tends to shrink as the world income increases (Engel's law) (Prebisch 1949; Vernengo 2016). It is therefore doubtful whether the peripheral Global South stands to gain relative power over industrialized countries thanks to being rich in rare earth materials. Instead, the pattern suggests they will remain in a position of underdevelopment.

Finally, it has been argued that structural dependence in finance may constitute an even stronger limitation of development and growth than technology dependency (Becker 2008; Tavares 1985), an argument that extends to the global energy transition. Renewable energy investment prominently relies on foreign capital in many countries. This fact gains special importance in phases of economic growth, when investments rise. The availability of foreign currency limits domestic accumulation processes (Becker 2008). Capital inflow is highly dependent on economic trends within the center. In phases of prosperity, the willingness to invest in the 'riskier' periphery is low. During times of little investment opportunities and excess liquidity (as we are currently facing at zero interest rates in Europe), investment in peripheral states picks up (Becker 2008). In turn, foreign debt rises, which in the past was seen as strengthening the creditors' hand over the debtors (e.g., through global financial agencies such as the IMF and the World Bank). This suggests that renewable energy investment in the Global South will remain a function of the economic cycles in the center-the Global North.

\section{Conclusion}

The global energy transition is likely to generate important benefits for countries in the Global South. At the same time, it will also throw up new questions and give rise to novel challenges. As this chapter argued, these challenges are likely to center on the trias of finance, technology, and trade. In each of these three aspects, there exists the potential for outright 'energy transition risk' for countries that have yet to catch up economically. To be sure, individual sectors such as the financial industry have started to take these risks seriously. By definition, however, individual sectors adopt stovepipe approaches, which presents a call on the scholarly community to make sense of the bigger picture.

This call is yet to be heeded. While some important scholarly work has been done, for instance, on the prospects of oil producer economies, much more effort is needed to comprehensively grasp the implications of the global energy transition for the Global South. As the discussion in this chapter suggests, there exists a serious chance of some of the Global South either not gaining access to low-carbon energy technologies, or of becoming technology-dependent. While China, officially still considered a developing country, has been able to 'upgrade' its place in the global low-carbon tech value chain, most of the Global South only sees technology diffusion. This may be enough to deliver important co-benefits in the shape of health effects, the empowerment of women, or decentralized energy access for local communities. It will not be enough to make developing countries climb up the economic ladder 
and industrialize on a low-carbon model - the idea that underpins the promise of leapfrogging. What is more, the poorest and least stable countries which either do not manage to participate in global (low carbon) value chains or fall out of it thanks to various carbon regimes ringfencing consumer blocs, run the risk of not transitioning. Such an uneven transition brings its own set of geopolitical consequences (Eicke et al. 2019).

In terms of theory, these challenges offer great potential for further analytical advancement. This chapter has suggested three approaches to make sense of trends and possible risks, but there may be more. Admittedly, the present bias towards left-leaning or outright Marxist approaches - dependency theory and critical IPEleaves open flanks for criticism. This, however, is intentional. Liberal theories, often the basis of cost-related energy technology diffusion arguments, rely on equally strong normative foundations and indeed assumptions that are hard to maintain in the very real-world setting presented by the global energy transition. To drive the point home again: while there is good reason to believe that solar PVs will help the poor across the planet thanks to falling unit costs, it would be false to ignore the underlying structural imbalances that have emerged over centuries of uneven global economic development. For the energy transition to become a fully global phenomenon, it is arguably these imbalances that need to be addressed.

\section{References}

Abbott KW (2009) Innovation and technology transfer to address climate change: lessons from the global debate on intellectual property and public health. In: Intellectual property and sustainable development series. International Centre for Trade and Sustainable Development (ICTSD), Geneva

Abdel-Latif A (2014) Intellectual property rights and the transfer of climate change technologies: issues, challenges, and way forward. Clim Policy 15(1):103-126

Akerlof G, Greenspan A, Maskin E, Sharpe W, Aumann R, Hansen LP, McFadden D, Shiller R, Baily M, Hart O, Merton R, Shultz G (2019) Economists' statement on carbon dividends. Wall Street J

Alstone P, Gershenson D, Kammen DM (2015) Decentralized energy systems for clean electricity access. Nat Clim Chang 5:305-314

Auty RM (1993) Sustaining development in mineral economies: the resource curse thesis. Routledge, London, UK, and New York, NY

Bahar H, Sauvage J (2013) Cross-border trade in electricity and the development of renewablesbased electric power

Baker D, Jayadev A, Stiglitz J (2017) Innovation, intellectual property, and development: a better set of approaches for the 21st Century. AccessIBSA

Baker L, Newell P, Phillips J (2014) The political economy of energy transitions: the case of South Africa. New Polit Econ 19(6):791-818

Baru S (2012) Geo-economics and strategy. Survival 54(3):47-58

Becker J (2008) Der kapitalistische Staat in der Peripherie: polit-ökonomische Perspektiven. Journal für Entwicklungspolitik XXIV(2-2008):10-32

Bell M (1990) Continuing industrialisation, climate change and international technology transfer. University of Sussex SPRU, Brighton 
Bell M (2012) International technology transfer, innovation capabilities, and sustainable development. In: Ockwell DG, Mallett A (eds) Low-carbon technology transfer: from rhetoric to reality. Routledge, pp 21-47

Binz C, Truffer B (2017) Global innovation systems-A conceptual framework for innovation dynamics in transnational contexts. Res Policy 46(7):1284-1298

Castellacci F (2011) Closing the technology gap? Rev Dev Econ 15(1):180-197

Chon M, Roffe P, Abdel-Latif A (2018) The cambridge handbook of public-private partnerships, intellectual property governance, and sustainable development. Cambridge University Press

CitiGPS (2015) Energy darwinism II. why a low carbon future doesn't have to cost the earth. CitiGroup, London

Collier P, Hoeffler A (2004) Greed and grievance in civil war. Oxf Econ Pap 56(4):563-595

Cox RW (2016) Gramsci, hegemony and international relations: an essay in method. Millenn: J Int Stud 12(2):162-175

Criekemans D (2018) Geopolitics of the renewable energy game and its potential impact upon global power relations. In: Scholten D (ed) The geopolitics of renewables. Springer, London, pp 37-74

Curran L (2015) The impact of trade policy on global production networks: the solar panel case. Rev Int Polit Econ 22(5):1025-1054

Dagnachew AG, Lucas PL, Hof AF, Gernaat DE, de Boer H-S, van Vuuren DP (2017) The role of decentralized systems in providing universal electricity access in Sub-Saharan Africa-A model-based approach. Energy 139:184-195

Dale G (2016) In search of Karl Polanyi's international relations theory. Rev Int Stud 42(3):401-424

Edenhofer O, Pichs-Madruga R, Sokona Y, Minx JC, Farahani E, Kadner S, Seyboth K, Adler A, Baum I, Brunner S, Eickemeier P, Kriemann B, Savolainen J, Schlömer S, von Stechow C, Zwickel T (2014) Climate Change 2014. Mitigation of Climate Change. Working Group III contribution to the fifth assessment report of the intergovernmental panel on climate change. Cambridge University Press, New York

Eicke L, Weko S, Goldthau A (2019) Countering the risk of an uneven low-carbon energy transition. IASS Policy Brief. Potsdam: Institute for Advanced Sustainability Studies

Fofack H (2008) Technology trap and poverty trap in Sub-Saharan Africa. World Bank, Washington, DC

Forsyth T (2007) Promoting the "Development Dividend" of climate technology transfer: can crosssector partnerships help? World Dev 35(10):1684-1698

Fraser N (2017) Why Two Karls are better than one: integrating Polanyi and Marx in a critical theory of the current crisis. In: Working Paper der DFG-Kollegforscher_innengruppe Postwachstumsgesellschaften 1/2017

Friedrichs J, Inderwildi OR (2013) The carbon curse: are fuel rich countries doomed to high $\mathrm{CO}_{2}$ intensities? Energy Policy 62:1356-1365

Gallagher KP, Zhongshu L, Mauzerall D (2018) Estimating Chinese Foreign investment in the electric power sector. In: GCI Working Paper 003(10/2018)

Gereffi G (2014) Global value chains in a post-Washington consensus world. Rev Int Polit Econ $1-29$

Gereffi G, Humphrey J, Sturgeon T (2005) The governance of global value chains. Rev Int Polit Econ 12(1):78-104

Gereffi G, Lee J (2012) Why the world suddenly cares about global supply chains. J Supply Chain Manag 48(3):24-32

Gilpin R (1987) The political economy of international relations. Princeton University Press, Princeton

Glachant M, Dechezleprêtre A (2016) What role for climate negotiations on technology transfer? Clim Policy 17(8):962-981

Goldthau A, Bazilian M, Bradshaw M, Westphal K (2019) Model and manage the changing geopolitics of energy. Nature 569(7754):29-31

Goldthau A (2017) The G20 must govern the shift to low-carbon energy. Nature 546:203-205 
Gosens J, Lu Y (2013) From lagging to leading? Technological innovation systems in emerging economies and the case of Chinese wind power. Energy Policy 60:234-250

Gramsci A (2011) Letters from prison. Columbia University Press, New York

Gribble JN, Bremner J (2012) Achieving a demographic dividend. Popul Bull 67(2):1-15

Hamilton A (1791) Report on the subject of manufactures. Philadelphia

Helgenberger S, Gürtler K, Borbonus S, Okunlola A, Jänicke M (2017) Mobilizing the co-benefits of climate change mitigation: building new alliances-Seizing opportunities-Raising climate ambitions in the new energy world of renewables. In: COBENEFITS IMPULSE (Policy Paper). Institute for Advanced Sustainability Studies (IASS), Potsdam

Horn H, Sapir A (2019) Border carbon tariffs: giving up on trade to save the climate?. Bruegel

IEA (2018a) Outlook for producer economies 2018. In: What do changing energy dynamics mean for major oil and gas exporters?. International Energy Agency (IEA), Paris

IEA (2018b) World energy outlook. International Energy Agency (IEA), Paris

IEA (2019) World energy investment 2019, Paris

Inayatullah N, Blaney DL (2016) Towards an ethnological IPE: Karl Polanyi's double critique of capitalism. Millenn: J Int Stud 28(2):311-340

IRENA (2018) Renewable power generation costs in 2017. Abu Dhabi

IRENA (2019) A new world. In: The geopolitics of the energy transformation. Masdar City

Johnson O (2016) Promoting green industrial development through local content requirements: India's National Solar Mission. Clim Policy 16(2):178-195

Jordana J, Levi-Faur D, Puig I (2006) The limits of europeanization: regulatory reforms in the spanish and portuguese telecommunications and electricity sectors. Governance 19(3):437-464

Karl TL (1997) The Paradox of plenty. In: Oil booms and petro states. University of California Press, Berkeley

Keohane N, Petsonk A, Hanafi A (2015) Toward a club of carbon markets. Clim Change 144(1):8195

Kirchherr J, Urban F (2018) Technology transfer and cooperation for low carbon energy technology: analysing 30 years of scholarship and proposing a research agenda. Energy Policy 119:600-609

Krane J (2017) Climate change and fossil fuel: an examination of risks for the energy industry and producer states. MRS Energy \& Sustain 4:E2

Kruyt B, van Vuuren DP, de Vries HJM, Groenenberg H (2009) Indicators for energy security. Energy Policy 37(6):2166-2181

Kuzemko C, Lockwood M, Mitchell C, Hoggett R (2016) Governing for sustainable energy system change: politics, context and contingency. Energy Res Soc Sci 12:95-105

Levin T, Thomas VM (2016) Can developing countries leapfrog the centralized electrification paradigm? Energy Sustain Dev 31:97-107

Lewis JI (2014) The rise of renewable energy protectionism: emerging trade conflicts and implications for low carbon development. Glob Environ Polit 14(4):10-35

List F (1841) Das nationale system der Politischen Ökonomie. Cotta'scher Verlag zu Stuttgart, Stuttgart

Manley D, Cust J, Cecchinato G (2017) Stranded nations? The climate policy implications for fossil fuel-rich developing countries. In: OxCarre Policy Paper 34

Meckling J, Hughes L (2017) Globalizing solar: global supply chains and trade preferences. Int Stud Quart 61(2):225-235

Mehling MA, van Asselt H, Das K, Droege S (2019) Beat protectionism and emissions at a stroke. Nature 559(321-324)

Mercure J-F, Pollitt H, Viñuales JE, Edwards NR, Holden P, Chewpreecha U, Salas P, Sognnaes I, Lam A, Knobloch F (2018) Macroeconomic impact of stranded fossil fuel assets. Nat Clim Change 8:588-593

Metz B, Davidson OR, Martens J-W, van Rooijen SNM, Van Wie McGrory L (2000) Methodological and technological issues in technology transfer. A Special Report of IPCC Working Group III. Cambridge University Press, Cambridge

Moran TH (1993) An economics agenda for neorealists. Int Secur 18(2):211-215 
Murphy K, Kirkman GA, Seres S, Haites E (2015) Technology transfer in the CDM: an updated analysis. Clim Policy 15(1):127-145

Nahm J (2017) Renewable futures and industrial legacies: wind and solar sectors in China, Germany, and the United States. Bus Polit 19(1):68-106

Newell P (2019) Trasformismo or transformation? The global political economy of energy transitions. Rev Int Polit Econ 26(1):25-48

Newell P, Bulkeley H (2017) Landscape for change? International climate policy and energy transitions: evidence from sub-Saharan Africa. Clim Policy 17(5):650-663

Newell P, Paterson M (2010) Climate capitalism: global warming and the transformation of the global economy. Cambridge University Press, Cambridge

Nordhaus W (2015) Climate clubs: overcoming free-riding in international climate policy. Am Econ Rev 105(4):1339-1370

O'Sullivan M, Overland I, Sandalow D (2017) The geopolitics of renewable energy. In: Working paper. Belfer Center for Science and International Affairs, Cambridge, MA

Ockwell D, Byrne R (2016) Improving technology transfer through national systems of innovation: climate relevant innovation-system builders (CRIBs). Clim Policy 16(7):836-854

Ockwell DG, Hauma R, Mallett A, Watson J (2010) Intellectual property rights and low carbon technology transfer: conflicting discourses of diffusion and development. Glob Environ Change 20:729-738

Overland I (2019) The geopolitics of renewable energy: debunking four emerging myths. Energy Res Soc Sci 49(March):36-40

Pirrong C (2014) The economics of commodity trading firms. Trafigura, Houston

Polanyi K (1957) The great transformation: the political and economic origins of our time. Beacon Hill, Boston, MA

Power M, Newell P, Baker L, Bulkeley H, Kirshner Joshua, Smit A (2016) The political economy of energy transitions in Mozambique and South Africa: the role of the Rising Powers. Energy Res Soc Sci 17:10-19

Prebisch R (1949) El desarrollo económico de América Latina y algunos de sus principales problemas. CEPAL, Santiago de Chile

Pueyo A, Mendiluce M, Naranjo MS, Lumbreras J (2012) How to increase technology transfers to developing countries: a synthesis of the evidence. Clim Policy 12(3):320-340

Raiser K, Naims H, Bruhn T (2017) Corporatization of the climate? Innovation, intellectual property rights, and patents for climate change mitigation. Energy Res Soc Sci 27:1-8

Rimmer M (2019) Beyond the paris agreement: intellectual property, innovation policy, and climate justice. Laws $8(1)$

Ross ML (2001) Does oil hinder democracy? World Polit 53(April):325-361

Ross ML (2012) The oil curse: how petroleum wealth shapes the development of nations. Princeton University Press, Princeton

Sachs JD, Warner AM (1995) Natural resource abundance and economic growth. In: Development discussion paper. Harvard Institute for International Development, Cambridge, 517a

Schmidt J, Gruber K, Klingler M, Klöckl C, Camargo LR, Regner P, Turkovska O, Wehrle S, Wetterlund $E$ (2019) A new perspective on global renewable energy systems: why trade in energy carriers matters. Energy Environ Sc

Schmitz H, Lema R (2015) The global green economy. In: Fagerberg J, Laestadius S, Martin B (eds) The triple challenge for Europe: economic development, climate change, and governance. Oxford University Press, pp 119-141

Scholten D (ed) (2018a) The geopolitics of renewables. Routledge, London

Scholten D (2018b) The geopolitics of renewables-An introduction and expectations. In: Scholten D (ed) The geopolitics of renewables. Springer, London, pp 1-36

Schwarz R (2008) The political economy of state-formation in the Arab Middle East: Rentier states, economic reform, and democratization. Rev Int Polit Econ 15(4):599-621

Seto KC, Davis SJ, Mitchell RB, Stokes EC, Unruh G, Ürge-Vorsatz D (2016) Carbon lock-in: types, causes, and policy implications. Annu Rev Environ Resour 41:425-452 
Tavares MC (1985) A retomada de hegemonia Americana. Revista de Economia Política 5(2):5-16

Tempest K, Lazarus M (2014) Estimating international mitigation finance needs: a top-down perspective. Stockholm Environment Institute, Stockholm

UNEP/BNEF (2018) Global trends in renewable energy investment 2018. Frankfurt

Unruh GC (2000) Understanding carbon lock-in. Energy Policy 28(12):817-830

Unruh GC, Carrillo-Hermosilla J (2006) Globalizing carbon lock-in. Energy Policy 34(10):11851197

Vandenbergh MP (2007) The new wal-mart effect: the role of private contracting in global governance. UCLA Law Rev 54:913

Vernengo M (2016) Technology, finance, and dependency: Latin American radical political economy in retrospect. Rev Radic Polit Econ 38(4):551-568

Watson J, Byrne R (2012) Low-carbon innovation in China: the role of international technology transfer. In: Ockwell D, Mallett AG (eds) Low-carbon technology transfer: From rhetoric to reality. Routledge

WBGU (2011) Welt im Wandel: Gesellschaftsvertrag für eine große Transformation. Hauptgutachten. Wissenschaftlicher Beirat der Bundesregierung für Globale Umweltveränderungen (WBGU), Berlin

Wright C (2018) Chinese overseas investments in fossil fuel 100x bigger than renewables since Paris. climatetracker.org

Zhang F, Gallagher KS (2016) Innovation and technology transfer through global value chains: evidence from China's PV industry. Energy Policy 94:191-203

Zhou C (2019) Can intellectual property rights within climate technology transfer work for the UNFCCC and the Paris Agreement? Int Environ Agreem 19:107-122

Open Access This chapter is licensed under the terms of the Creative Commons Attribution 4.0 International License (http://creativecommons.org/licenses/by/4.0/), which permits use, sharing, adaptation, distribution and reproduction in any medium or format, as long as you give appropriate credit to the original author(s) and the source, provide a link to the Creative Commons license and indicate if changes were made.

The images or other third party material in this chapter are included in the chapter's Creative Commons license, unless indicated otherwise in a credit line to the material. If material is not included in the chapter's Creative Commons license and your intended use is not permitted by statutory regulation or exceeds the permitted use, you will need to obtain permission directly from the copyright holder.

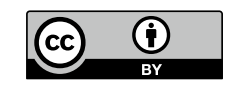

